\title{
The Cathedral of Straw
}

\author{
La catedral de paja
}

João Alves da Cunha · FAUTL-Lisbon's Faculty of Architecture (Portugal)

https://doi.org/10.17979/aarc.2013.3.0.5106

\section{RESUMEN}

Esta comunicación se hace eco de las grandes celebraciones eucarísticas celebradas en ocasiones por la Iglesia católica en lugares públicos, y propone algunas pautas para su desarrollo. Para ello, utiliza los ejemplos de las misas celebradas recientemente por el papa Benedicto XVI en Valencia (2006) y Lisboa (2010), el papa Francisco en Lampedusa (2013), y una misa celebrada en Fátima por el Prepósito General de la Compañía de Jesús, padre Adolfo Nicolás (2008). A través de estos casos, se puede ver cómo una construcción pobre y sencilla generada por una arquitectura humilde puede ser tan hermosa y noble como la más rica. Pero lo más importante es que en este último caso, su testimonio cristiano se hace más creíble.

\section{ABSTRACT}

This communication reflects on the great Eucharistic celebrations held occasionally by the Roman Catholic Church in public places and proposes some guidelines to its development. To do this, it uses the examples of the Masses held by Benedict XVI in Valencia (2006) and Lisbon (2010), the Mass by Pope Francis in Lampedusa (2013) and finally a Mass celebrated in Fatima by General of the Jesuits Father Adolfo Nicolás (2008). Through these cases is visible how a poor and simple construction generated by a humble architecture can be as beautiful and noble as the richest. But more importantly, its testimony of Christ becomes considerably more credible.

\section{PALABRAS CLAVE}

Grandes misas; espacio público; simplicidad; economía; arquitectura religiosa.

\section{KEYWORDS}

Big Masses; Public Space; Simplicity; Economy; Sacred Architecture. 
Fig. 01. Mass in Valencia, 2006.

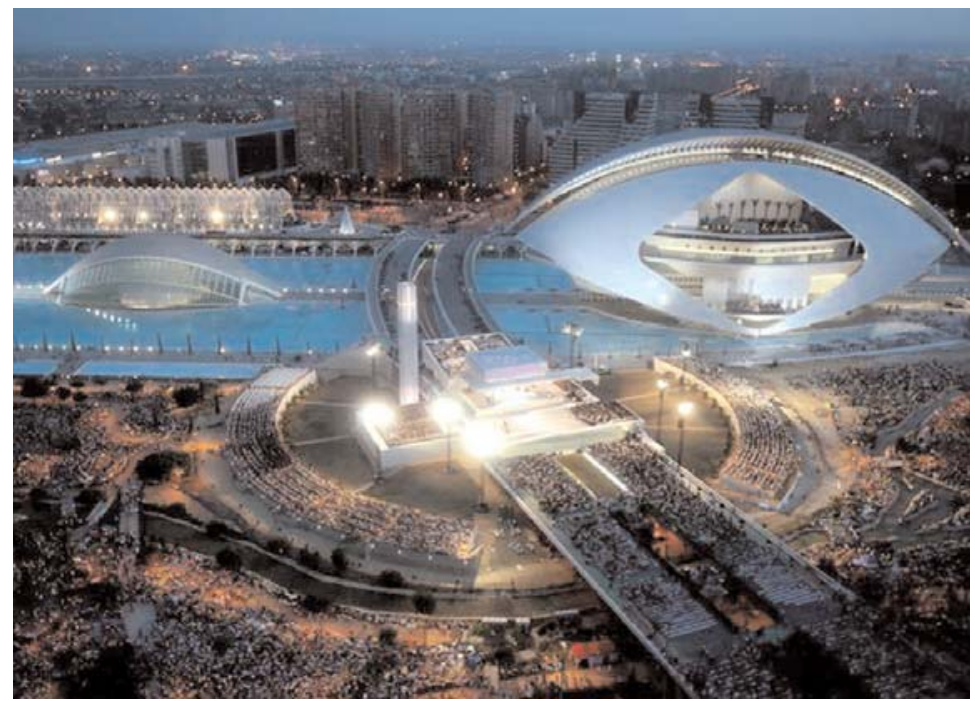

Sunday, July 9, 2006. I woke up in the Saint Ignatius' Retreat House, near Sintra, where I was doing a week of Spiritual Exercises. After a night praying the passion, death and resurrection of Jesus, I woke up excited for what was the last day of the retreat and decided to walk through the gardens before heading to the breakfast room. However, my journey was interrupted in the entrance when I saw the news in the newspaper (Expresso, July, 8th, 2006) screaming in the title «Valência vai receber Papa com luxo» (Valencia will welcome Pope with luxury) (Fig. 01). Caught by surprise, I could not resist to continue reading the article, which spoke of the beginning of the visit of Pope Benedict XVI to Spain and the contestation from different sectors of the Catholic Church, who lamented the «papolatry» environment and the «impressive expenses paid to receive the Pope», as the 600.000 euros paid for the altar where the Pope would be two and half hours and the works carried out in the Episcopal House to host Benedict XVI for just one night, expenses considered by Father Antonio Garay as «an ostentation contrary to the Gospel and a moral violence to the poor». It was impossible to keep the news away from my thoughts the rest of the day and it was even harder to accept the Rules to feel with the Church that St. Ignatius of Loyola proposed in section 365 of the Spiritual Exercises Book. Fortunately, the Holy Spirit rescued me (once again), by showing me that the Church is an imperfect pilgrim just like I am. And this means that a lot of times we relapse in our mistakes...

Four years later, Benedict XVI returned to the Iberian Peninsula, this time traveling to Portugal for a visit to Lisbon, Fatima and Porto. Its passage through the Portuguese capital was marked by a Mass held on May 11 at Praça do Comércio, a square that is a major symbol of the political power and the history of a city opened to the river and from here to the world. It was precisely above these waters that a vast temporary structure inspired by the pebbles of the river Tagus was raised, to frame the stage where Benedict XVI and 65 other bishops sitting in Victoria Ghost chairs by Philippe Starck, celebrated the Eucharist with 80.000 people for two hours. Once again, for its cost — 200.000 euros — and limited use, the monumental temporary church erected at that time became an easy target to critics, and gave rise to a noise that obscured the Christian message it should helped proclaim (Fig. 02). For those who love the Pope, the Mass was a festivity that would have happened anyway, with that structure or a simpler one. For those who are far from the Church, it was a bad testimony, aggravated by the harsh economic crisis that Portugal was already living. The excesses of the architectural solution filled the eyes of a few, but for many it was one more reason not to approach the Catholic Church. 


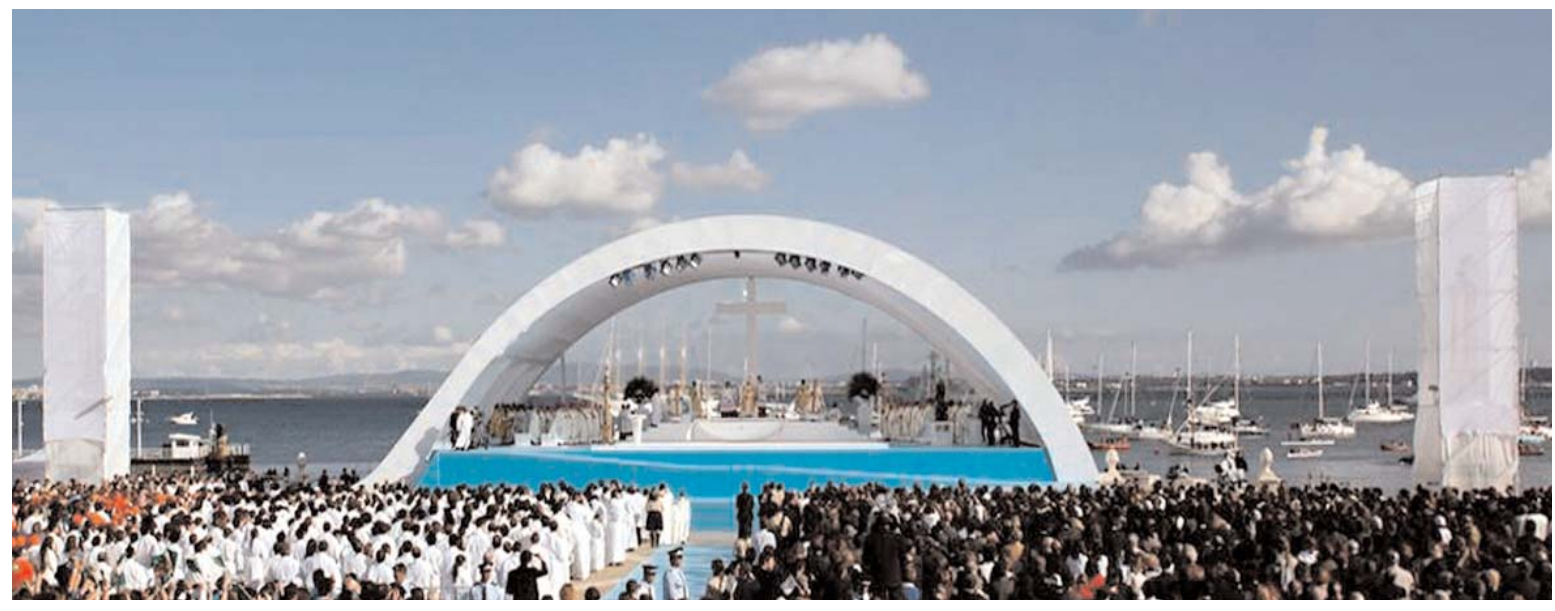

Fig. 02. Mass in Lisbon, 2010.

This theme of great Eucharistic celebrations held occasionally by the Church in non-liturgical places took a particular spot in our attention in early 2008, when we were invited to prepare the ground for a Mass that Christian Life Community -an international lay movement accompanied by the Jesuits - would held in August during its XV World Assembly, which took place that year in Fatima. Beyond the natural enthusiasm resulting from the challenge to think a Mass for more than a thousand people from dozens of countries around the world, there was an additional stimulus when we knew that the president of the celebration would be the new General of the Jesuits, Father Adolfo Nicolás, who would come to Portugal purposely to attend this meeting.

After several hypotheses discussed, like the use of a larger church in the center of Fatima or a sports venue close located, it was approved the proposal to hold the Mass outdoor, in a flat area framed by numerous trees in the gardens of the home where the World Assembly was happening. Given the natural beauty of the place and the short duration of the event, two rules to be met by the architecture were automatically defined: humility and economy. Humility in recognizing the great landscape value of the area, which meant that the elements that we needed to introduce in that garden should place in harmony with the existing ones. And economy in understanding the uniqueness of the celebration, which meant that we should care about using reusable materials and assure its low cost.

That's how the liturgical space gained body with simple and poor materials, not usually associated with the liturgy. Altar, ambo, chair, seats of the gathered assembly, everything would be made from straw bales, which would gain a humble and dignified beauty in those hours. The idea was conveyed to the organization, which joyfully accepted. It was then time to implement it. A fast search found a producer who agreed to lend the straw bales for a day. Another contact made us find an owner of a truck that was willing to carry the load from the farm to the location of the mass in Fatima, 70 kilometers distant from one another. Then, with the measures of the bales, we studied their best disposition and tested the altar in the barn of the farm. So when the time came, everything was ready.

Fig. 03. Mass in Fatima, 2008; unloading (on the opposite page)

Fig. 04. Building.

Fig. 05. The site.

Fig. 06. Welcome.

Fig. 07. The choir.

Fig. 08. The sign of peace. 

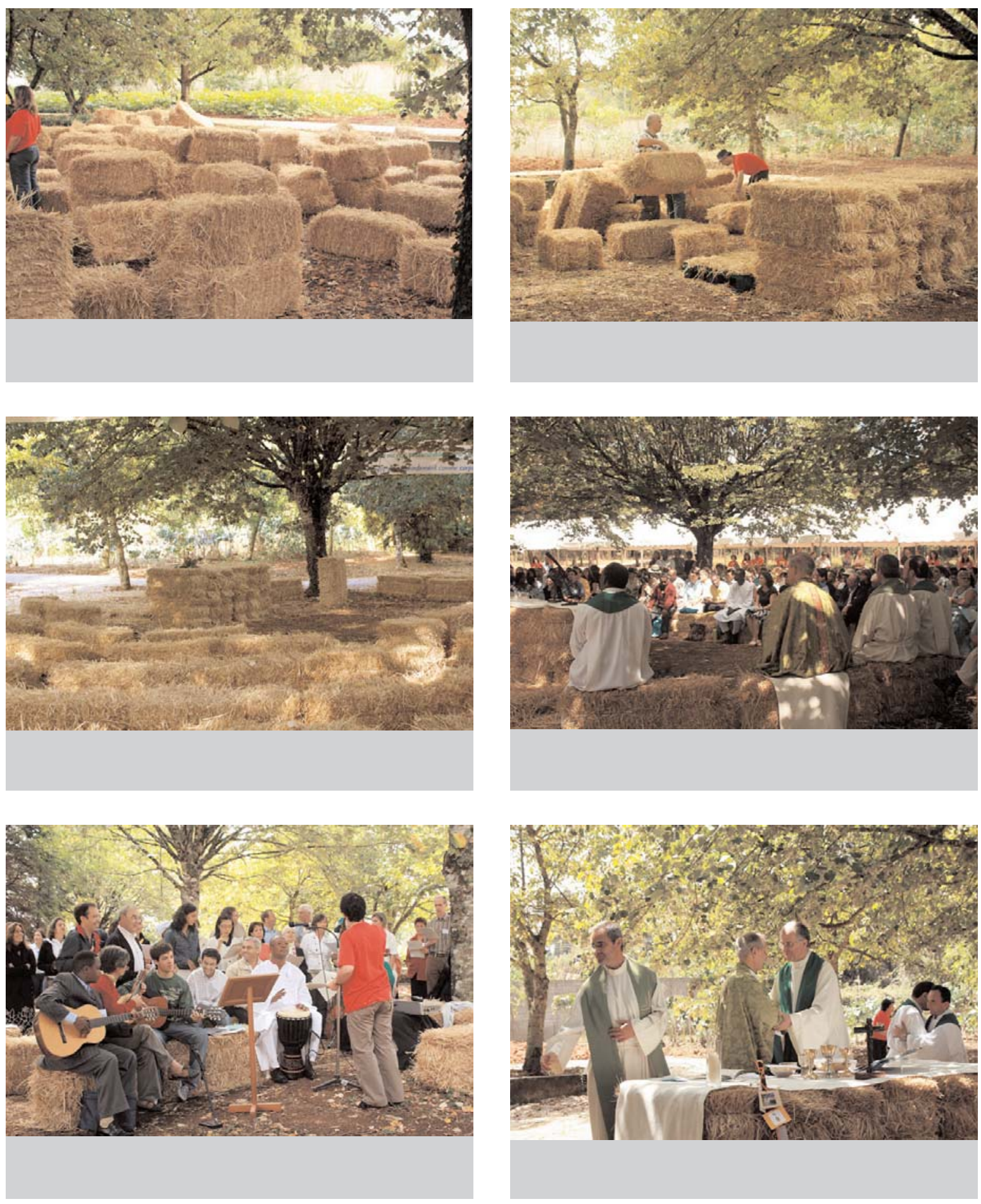


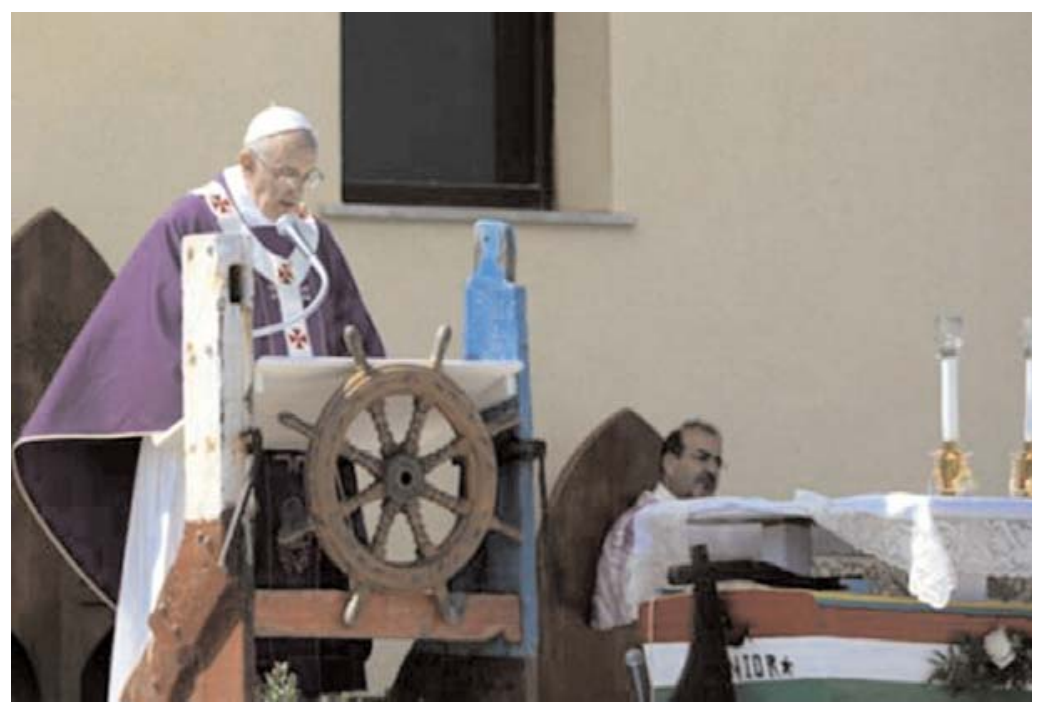

Fig. 09. Mass in Lampedusa, 2013.

Early in the morning of August 17, we joined the truck loaded with more than 100 bales on its trip to Fatima. On arrival there were many smiling faces that revealed the will to help building something that they had only heard until that moment. In the construction of the celebration space, which took no more than an hour, many of those present participated, since the removal of the load from the truck to its storage on the ground. The construction of the church produced its first fruit at that time: in a unique and particular manner, it helped to significantly strengthen the community gathered there. When the set was placed, everyone identified that simple and humble space as truly Christian, a place made of straw bales which rested peacefully in nature. Mass presided by Father Adolfo Nicolás sj took place in a festive atmosphere of great proximity, favored by the discrete beauty of the straw bales, which served with distinction his mission, stripped from luxury or any other kind of royalty. And the Church gathered there recognized itself in the noble simplicity of that space, which soon earned the name Cathedral of Straw (Fig. 03-08).

At the end of the day, the straw bales were already back in its farm. From the Cathedral of Straw there was nothing left, beyond the memory of the celebration that persisted within each one present. In the days that followed, multiple testimonies delighted with the participa- tion in a Mass lived between straw bales appeared. In the evaluation made, the fruits generated by an architecture that puts itself at the humble service of the Church were very visible. Through this case, we clearly perceived that a poor, simple and honest construction can be as beautiful and noble as the richest one, but more importantly, its testimony of the evangelical life is considerably more credible.

In a time when luxury and waste are reasons for scandal for every one of the millions who live in poverty, the Catholic Church must have really present its roots among the poor and the excluded. And it must have a greater awareness that nowadays, every step it takes and every word it says, are seen, read, checked and evaluated by thousands of media and millions of people who exchange messages at an immense velocity on social networks around the world. Its credibility and consistency are always under evaluation. The Catholic Church has, therefore, to assess the way it uses architecture in its celebrations and in a particular way in the large Masses that occasionally performs in public places, so it can really choose the architecture that brings people more close to God and to the Church, not just thinking in the ones that are believers, but also and in a particular way in those that are not.

This seems to be just what is being implemented right now by Pope Francis, in a move that is certainly 
not oblivious to the will of wanting a Church poor and for the poors that he has manifested since the beginning of his pontificate. His trip to the island of Lampedusa is paradigmatic and has much to do with the topic we are now concerned. Regarding the architecture of liturgical space, we find that the Mass the Pope celebrated there on last July also made the news — and always with a positive review - because of the choices made regarding the liturgical elements used. The photographs shown and the newspapers spoke of an altar that was a boat that once sunk, and a pulpit and a cross made from materials also recovered to the sea (Fig. 09). We do not intend at this time to evaluate the aesthetic quality of these elements, but only the strength of their testimony.

With this poor and humble architecture, the Pope's words were amplified and its message could actually be heard without controversy or aesthetic noise. The criticism made in his homily to the culture of wellness and the globalization of indifference came to our ears and with the collaboration of architectural simplicity; his question Who wept in the world today? also reached deep into our hearts. In Lampedusa, with very little, materially speaking, much has been achieved, spiritually speaking. So, inspired by this example, we join Father Marie-Alain Couturier op, and we state with him, in a lesson to the architecture of great Eucharistic celebrations: «The glory of God is not in richness and enormity, but in the perfection of a pure work. If our churches were like that, they could start teaching the world that very little is needed to the essential in life» ${ }^{1}$.

\section{PROCEDURE OF IMAGES}

Author's archive.

\section{NOTES}

(1) This quote was written on one of the panels of the exhibition Contemporary Architecture Religious, held in Lisbon in 1953 by the Movement for Renewal of Religious Art (MRAR). 